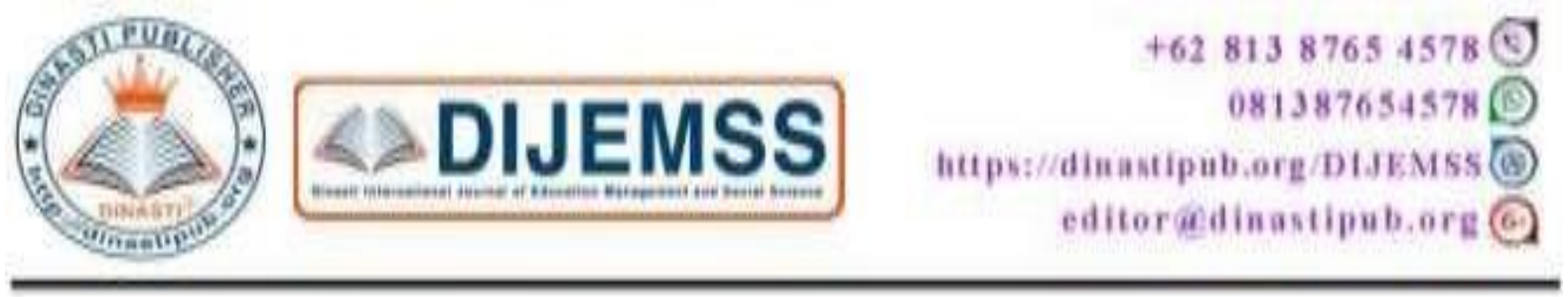

\title{
GROWING THE CREATIVITY AND IMAGINATIVE OF STUDENTS TO IMPROVE NATIONAL COMPETITIVENESS
}

\section{Endang Solichin}

Economic Education Department, STKIP YPM Bangko, Indonesia

\begin{tabular}{|l|l|}
\hline ARTICLE INFORMATION & $\begin{array}{l}\text { Abstract: Education changes behavior because with } \\
\text { Received: 08/10/2019 } \\
\text { Revised: 13/10/2019 } \\
\text { Issued: 18/10/2019 }\end{array}$ \\
$\begin{array}{l}\text { Corresponding authes in knowledge will have an impact on changes } \\
\text { in attitudes and actions, when education does not } \\
\text { produce changes in behavior means there are problems } \\
\text { in the education process. Educators must foster the } \\
\text { creativity and imaginative of students to give birth to } \\
\text { innovative behavior, so that they can improve the } \\
\text { nation's competitiveness. The purpose of this study is } \\
\text { to understand the appropriate educational model in the } \\
\text { era of industrial revolution 4.0 which emphasizes } \\
\text { creativity and innovation. The method used in this } \\
\text { study is a qualitative method by tracing and analyzing } \\
\text { the implementation and results of the educational } \\
\text { process with a focus on attention to behavior change. } \\
\text { The results of this study found that the educational } \\
\text { model must move to a new area created with creativity } \\
\text { and imagination, not focusing on the fight against } \\
\text { existing competition, this strategy encourages people } \\
\text { to be more creative, create added value and be able to } \\
\text { create new things. } \\
\text { Keywords: Creativity, imagination, innovative } \\
\text { behavior. }\end{array}$
\end{tabular}

\section{INTRODUCTION}

Education must give birth to behavioral changes, therefore the educational model applied must be visionary, not follow the developments but must create or design developments in the future. The development of society towards the era of the industrial revolution 4.0 has made the world of education aware of the need to change the educational model to be able to answer the challenges of these changes. This means that the education 
model adopted follows the development of society or the industrial world, this is a problem so that education is always behind the development of society or the industrial world.

The 4.0 industrial revolution is an area where creativity and innovation are the core, so intellectual capital is the main thing, not the physical wealth anymore. Society as a whole and especially the education world must have moved to an area where creativity and innovation are key, to create superior human beings not just to win the game, because the two concepts are very different, the target of winning the battle in the implied efforts to weaken the opponent or even destroy opponents, in contrast to superior targets, where added value will be the core that must be achieved, so that the concept of mutually raising or exalting each other is not mutually weakening or killing each other.

The core problem in dealing with the revolution era 4.0 is how people, especially the world of education, can migrate or jump into the ocean of creativity and innovation or the blue ocean which is fertile ground to foster creativity and imaginative and innovative power, to produce superior students, while the world of education still struggling in the red ocean or red ocean where the products produced are still trying to win a match or a fight.

\section{LITERATURE REVIEW}

Changes in behavior for a person occur through the existence of an educational process that is related to self-development as an individual. There are four changes, namely changes in knowledge, changes in attitudes, behavior changes and group changes. Change is something that requires time, change of knowledge is the easiest and requires relatively short while group changes are relatively the most difficult and the longest time.

There are two types of change cycles that cover the four types of changes, the first cycle is called the participatory cycle of change, the participatory cycle of change starts from a change in the personal first in terms of knowledge, with changes in knowledge that will change attitudes and then impact on changes in behavior, if the individuals have changed then the group will change. The two changes are directed, starting from the strength of one's self, namely from the position of power, environment or power of attorney.

Changes are directed more towards the use of power or power to change behavior, this change is directed from top to bottom, meaning that this change is imposed from above or from the holder of control to change group behavior, in this change more authoritarian forces force groups to change.

Participatory change is a change that is based on the awareness to change, this change is from the bottom or from the individuals themselves, for example the awareness to read will increase their knowledge, and with increasing knowledge the attitude changes, if there is a change in attitude then further changes also his actions, if the individuals have changed then the group changes.

The model of change that is directed more precisely applies to individuals whose level of maturity is still low both mentally and physically, so that the model of command and instruction will be more appropriate, different from participatory change more appropriately applied to individuals who already have a level of maturity, they aware of change, they will find out about what they want to know by reading and from what they read will shape their attitudes and behavior. 
Changes are directed precisely for high school education down so that the teacher acts as a power figure that changes student behavior, in the changes that are made, the teacher holds a key role as locomative which brings changes in student behavior. In contrast to participatory change it is more appropriate to apply to higher education, which is assumed by students to be more mature than high school students down, so that changes in students are based more on self-awareness to change by reading means to add value to knowledge, increased knowledge will affect attitude and behavior.

\section{RESEARCH METHODS}

The method used in this study is a qualitative method by tracing and analyzing the implementation and results of the education process with a focus on attention to behavior change towards students in Merangin District.

\section{Empirical data and analysis}

The observations show that the creativity and innovation of students in general still have to be encouraged to grow and develop, there are various aspects that become problems in this case, besides cultural or environmental factors, and the predominantly patterned educational model is in the red ocean.

Education models that are still struggling with efforts to print or prepare students who have to win battles, such a pattern in practice will encourage the incentive to light up in an important way to win the fight not in an effort to increase added value to him. This pattern will only give birth to winners not those who have superior value, this pattern exists in the red ocean region which always emphasizes the pattern of the battle to win the competition with blood.

\section{FINDINGS AND DISCUSSION}

Behavior changes as a result of education, whether directed changes or participative changes must emphasize the elements of creativity and imagination that provide added value and have excellence for students or students so that they are able to compete [1]. Many factors that influence changes in one's innovative behavior both internal factors and culture factors [2]. The internal factor is more about the belief factor, such as worry, doubt, lack of confidence and pessimism, therefore the formation of self in an effort to manage themselves becomes important, meaning the formation of student soft skills becomes urgent. There are two elements that make up a person's soft skills, namely intrapersonal skills and interpersonal skills. Intrapersonal skills are related to the ability to manage oneself so that the locus of control is in itself not from outside himself or others. The ability to manage oneself becomes important before developing oneself to interact with others, meaning that before developing interpersonal skills then it is better to be able to fix themselves first, namely the ability to manage themselves first prioritized.

The world of work views that superior human resources are those who not only have the skills of hard skills but also have expertise in soft skills aspects which means they are related to communication skills, organizational skills, leadership, cooperative skills and ethics [3]. Research at Harvard University in the United States shows that one's success is not 
determined solely by the knowledge and ability of the technical or hard skills but rather by the ability to manage themselves and others or their soft skills.

The study revealed that someone's success was eighty percent determined by soft skills and their skills, namely twenty percent by technical skills or hard skills. This inspires that education that has been filled with technical skills must be balanced with communication skills, organizational skills, cooperative leadership skills and ethics. These soft skills can be honed through organizational activities, because in organizational communication skills, group skills, leadership can grow.

While cultural factors are also often an obstacle to innovative behavior such as strict rules so that people do not have space to move freely, unusual habits of life spurred by a sense of competitiveness, family attitudes that are more protective because too much love for their children is a problem that stands out in accelerating maturity process and innovative behavior change. The culture of society is taboo about new things, such as new thoughts, even the rejection of change, the tendency to maintain status quo, this inhibits faster changes, the nature of accepting what is this is something that is not conducive to accelerating change.

Changes in innovative behavior in higher education are more research and development, behavior patterns arise when higher education people have an adventurous spirit to find something new, and are not trapped by a monotonous, established and patterned life, therefore curiosity and searching for something new in research and development must be grown and become a spirit that is always burning in academic people, education can also foster innovation in the wider community by developing the right skills to nurture it. These skills, including critical thinking, creativity and imagination, can be fostered through proper teaching, and practices such as entrepreneurship education [4].

Educators must be able to grow and provide space for students to think creatively and behave innovatively [5]. Creativity is a mental process in bringing up new ideas and concepts, so that these concepts become real values that need to be transformed and implemented through innovation, so innovation is an act of transforming ideas into action. creative thinking means being bold differently to think or issue new ideas that others have not thought of, getting used to not patterned thinking, meaning daring to get out of the way of common thoughts, innovative behavior means acting not like most people. Education in higher education must foster innovative behavior of students, therefore lecturers as educators must be able to provide space and movement to them, so that day by day they can get added value. Strengthening this belief factor is important, because what is believed and planted in the mind will produce action, without realizing that what is implanted in the mind is a good and a bad thing, the mind will immediately receive, respond and grow it. If those who are planted in the mind feel pessimistic, the mind will accept, respond and grow it, without realizing the words planted in our minds such as negative words "I will not succeed" then it will be called by the mind in the form of attitudes and actions that will produce something just as implanted in the mind. Educators in fostering optimism should stimulate students to grow positive things in their minds that will give birth to positive actions.

Innovative behavior is all behavior that is directed to produce, introduce, apply new things that are useful, there are two dimensions in innovative behavior, namely dimensions of creativity and risk taking. Creativity is the ability to develop new ideas consisting of aspects of expertise, the ability to think flexibly and imaginatively and the existence of internal 
motivation. In implementing the idea it takes courage to take risks because applying something new has risks. Encouraging new ideas to be applied will be faced with obstacles that face so that risk taking is a way to realize creative ideas into reality.

The currently popular value creation strategies are value innovation strategies, from $\mathrm{W}$. Chan Kim and Renee Mauborgne (2005), which divide the two strategies into two oceans, namely red ocean and blue ocean, in red ocean or red ocean people focus on fighting against existing competition, fighting each other bloody and tiring, energy runs out just to win the battle by weakening the opponent, this strategy is very weak, because the energy possessed is only to weaken the opponent instead of raising added value, competing with competitors through mutual defeat to no longer relevant, a smarter strategy is to leave the red ocean or the red ocean and jump to the blue ocean or the blue ocean which is an area created with creativity and imagination [6]. Blue ocean is an attitude in seeing the fact that if you want to win the competition elegantly, you must always be creative so that you can create new markets that bring and give more value to customers, the blue ocean strategy is a way of thinking that encourages more creative, creates added value and is able to create things the new, blue ocean is a way of thinking to create new things that make special and different.

Higher education does not only equip students to become fighters in competition, rather to foster innovative creativity and behavior [7]. Creativity and innovative behavior that provides added value to him, so that it is more directed at efforts to improve the quality of oneself which gives added value to him so that he becomes superior individuals, more focused on continuous self-improvement, which is what the people in Japan referred to as Kaizen, not to weaken rivals.

Paradigm Educators in Indonesia must dare to jump into the blue ocean, namely to the area of creativity and imagination, because the structure of the world economy has now gone far away from physiocratic ideals, which are based on physical strength such as land, who controls the land he will control the world, switch to non-capital physical in the form of intellectual capital, there are two differences from these two aspects, physical resources will gradually decrease in value, for example the level of fertility, and will be narrow in line with population growth, while intellectual capital will never run out in accordance with technological development and development research. Howkins (2001) argues that ideas, imagination, inspiration and wealth are sources of strength or resources that have more power than physical wealth, such as machinery and other real items. Howkins found that copyright in the United States has an export sales value of 60.18 billion dollars, or around 600 trillion, which far exceeds the exports of other sectors such as automotive, agriculture and aircraft[8].

\section{CONCLUSION AND SUGESTION}

Behavior changes occur through an educational process related to self-development, therefore education must foster innovative behavior based on creativity and imagination to form superior human beings. In today's era of economic development where people who have ideas have become stronger or more powerful, this shows that ideas, imagination, inspiration and imagination or dreams are sources of strength or resources that have more power than physical wealth, such as machines and other real goods, and nations that can win the competition are nations that place the management of intellectual capital to achieve national excellence. 


\section{REFERENCE}

Drucker, P.F, 1991, Inovasi dan kewirausahaan : Praktik dan Dasar-dasar. Terjemahan,Rusdji Naib, Jakarta, Erlangga

Suryana, 2013. Ekonomi Kreatif, Ekonomi baru : mengubah ide dan Menciptakan Peluang Penerbit Salemba Empat Jakarta

Yulia, Membangun daya saing bangsa melalui Pendidikan :Refleksi profesionalisme guru di era globalisasi, IAIN Iman Bonjol Padang.

OECD(2016), Innovating Education and Educating for Innovation : The Power of Digital Technologies and Skills, OECD Publishing, Paris.

Tilaar, H.A.R, Beberapa Agenda Reformasi Pendidikan Nasional dalam Perspektif Abad 21, Magelang : Indonesia Tera, 1999

Kim W.C. Renee M, 2005, Blue Ocean Strategy, INSEAD Institute

Departemen Pendidikan Nasional RI, Pembangunan Pendidikan Nasional, Jakarta depdiknas 2008.

Howkins, J. 2001. The Creative Economy : How people make money from Ideas. LondonEngland : Penguin Books Ltd. 80 Strand 